\title{
Death and the Bishop of Rome. From Hormisdas to Sabinian
}

\author{
Bronwen Neil \\ Australian Catholic University, Brisbane \\ Bronwen.Neil@acu.edu.au
}

\section{Summary}

The sixth to early seventh centuries was a dangerous period to be crowned a bishop of Rome. Over the course of ninety-two years, from 514 to 6o6, there were no fewer than fifteen bishops of Rome, including one anti-pope. In the decade from $5^{26}$ to 536 , six popes went to their graves. Very few of these bishops died in their beds. Their deaths were as significant as their lives for what they can tell us about the processes of election and the protections that their office afforded them, as well as the risks to which they were exposed. In many cases the sole witness to the manner and timing of their deaths is the Liber Pontificalis. ${ }^{1}$

\section{Keywords}

6th-7th century popes - Hormisdas - Sabinian - Liber Pontificalis

\section{Introduction}

Whether the end of Late Antiquity is rightly considered a period of crisis and decline or one of positive transformation has recently become an issue of debate. $^{2}$ An analysis of how long the bishops of Rome reigned and how they

1 This survey will help to explain the tenuous relationships that Roman bishops had with eastern emperors and patriarchs from the end of the Acacian schism to the time of Gregory the Great's successor Sabinian.

2 See e.g. A. Cameron, "The Perception of Crisis," Settimane di studio del centro italiana sul'alto medioevo, 45 (1998), pp. 9-31; B. Ward-Perkins, The Fall of Rome and the End of Civilization, 
died may shed some light on the health of the institution in the sixth century. Bishops of Rome during this period were called upon to shoulder more burdens for civic administration than previously, due to the breakdown of municipal government, the demise of the Roman senate and, from 476 until 536 , the lack of an imperial presence in the western Roman empire. Using the letters, hagiography and the Liber Pontificalis ${ }^{3}$ as the main sources, I consider the careers of Roman bishops in the sixth to early seventh centuries, focusing on the exceptionally short duration of many of their reigns and their often violent manner of death. This survey will help to explain the tenuous relationships that Roman bishops had with eastern emperors and patriarchs from the end of the Acacian schism to the time of Gregory the Great's successor Sabinian.

We begin our brief studies with the election of Hormisdas, omitting the pontificate of Symmachus (498-514), who has been the subject of several recent studies. ${ }^{4}$

\section{Hormisdas (514-523)}

In the sixth century, only four out of fourteen bishops of Rome originated from the provinces. The first of these was Hormisdas from Frusino, Campania, the last his son Silverius. (The other two were Popes John I and Felix IV, to whom we return below). The remaining ten were born in Rome, and six - Boniface II, Agapitus, Vigilius, Pelagius I, John III, and Gregory I - were from the Roman aristocracy. ${ }^{5}$ Hormisdas is best known as the orchestrator of the resolution to

Oxford, 2005, arguing strongly for overwhelming evidence of decline; P. Sarris, Empires of Faith: The Fall of Rome to the Rise of Islam, 500-700, Oxford, 2011; P. Booth, Crisis of Empire. Doctrine and Dissent at the End of Late Antiquity (Transformation of the Classical Heritage, 52), Berkeley - Los Angeles - London, 2014, esp. 15-22 on the spiritual crisis of the second phase of Origenism.

3 Le Liber Pontificalis, éd. L. Duchesne and C. Vogel, vol. 1, Paris, ${ }^{2} 1955$ (henceforth LP 1). All translations are taken from R. Davis, The Book of Pontiffs (Liber Pontificalis). The Ancient Biographies of the First Ninety Roman Bishops to AD 715 (Translated Texts for Historians, 6), Liverpool, ${ }^{2} 2000$.

4 These include E. Wirbelauer, Zwei Päpste in Rom. Der Konflikt zwischen Laurentius und Symmachus (498-514) (Studien und Texte), Freiburg, 1993; K. Sessa, The Formation of Papal Authority in Late Antiquity: Roman Bishops and the Domestic Sphere, Cambridge, 2012, pp. 208246; Demacopoulos, The Invention of Peter, pp. 103-116.

5 On the social and geographical provenance of late-antique popes, see J. Richards, The Popes and the Papacy in the Early Middle Ages 476-752, London - New York, 1979, pp. 240-242; J. 
the Acacian schism, the thirty-five year controversy that vexed relations between Rome and the eastern churches in the late-fifth to early-sixth centuries. While the majority of Hormisdas' 125 letters concern the schism, they also illustrate the workings of the papal scrinium, the development of the office of papal legates, the bishop of Rome's relationships with various other patriarchates, and his bonds of patronage with the imperial family and members of the aristocracy. ${ }^{6}$ Hormisdas produced his voluminous correspondence in Rome between 515 and 521 . The schism officially started with Felix III's condemnation in 484 of Peter of Antioch, Timothy Aelurus of Alexandria, his successor Peter of Alexandria, and the patriarch of Constantinople, Acacius (471-489).

The origins of the schism lay in imperial politics and the unfinished business of the Council of Chalcedon (451), which had failed to find a solution to a complex Christological problem (the nature of the union of human and divine natures in Christ) that could satisfy all the interested parties: the churches of Constantinople, Rome, Egypt, Syria, and Palestine. Many Alexandrians stayed loyal to their patriarch Dioscorus, who was deposed at the Council of Chalcedon and died soon afterwards. His main source of inspiration was the archimandrite of Constantinople, Eutyches, whose extreme interpretation of Cyril of Alexandria's statement "one incarnate nature of God the Word" had also been condemned at Chalcedon. Eutychian "one-nature" (miaphysite) Christology could not be easily stamped out. ${ }^{7}$

Amid the disunity in the East that followed Zeno's issue of the Henotikon, it was not surprising that the Acacian schism continued until 519. The end of Emperor Anastasius I's long rule in July 518 paved the way for a new era of reconciliation. Hormisdas initially found himself up against the decision of Anastasius I (491-518) to abide by Zeno's Henotikon of 482, which had been intended to achieve union between Rome, Constantinople, and the eastern churches, with dismal results. The Henotikon passed over the Council of Chalcedon in silence, neither accepting nor rejecting it. The church historian Evagrius of Caesarea reports that each bishop was allowed to maintain the Christological

Moorhead, "On Becoming Pope in Late Antiquity," Journal of Religious History, 30.3 (2006), pp. 279-293.

6 On papal letter-collections in the fifth and sixth centuries, see B. Neil, "Papal Letters," in: A Critical Introduction and Reference Guide to Letter Collections in Late Antiquity, ed. C. Sogno, B. Storin, E. Watts, Berkeley - Los Angeles, forthcoming.

7 See V.Menze, Justinian and The Making of the Syrian Orthodox Church (Oxford Early Christian Studies), Oxford, 2008, pp. 15-52, on its later stages from the accession of Justin I, its resolution and the consequences for the estranged East Syrian church. 
status quo in his see. The situation became even more absurd, he relates, because "the prelates of the East were not even in communion with each other, nor indeed were those directing the sees of Europe with Libya, and much less so with outsiders". 8 In the following year, Hormisdas finally conceded to the new emperor Justin's demand that he lift the Roman excommunication of Acacius. ${ }^{9}$ In return, Justin agreed to remove the names of Acacius, Peter of Alexandria, and Peter of Antioch from the liturgical diptychs. Even in 521, the ripples were still settling, as we see in Hormisdas' lengthy letter to Emperor Justin born in the Latin-speaking region of Dardania, 68 years of age when he acceded to the throne, and apparently illiterate - giving a response to the emperor's questions about Peter the Fuller's addition of the phrase meaning "one of the Trinity (was) crucified" to the Trisagion hymn. ${ }^{10}$ This phrase was to return to haunt the papacy of John II. Hormisdas died of natural causes after nine years on the papal throne, leaving the papacy at the height of its strength for several centuries to come.

The first pope of the sixth century to die a violent death was John I, a native of Tuscany. He took part in a senatorial embassy sent by Theoderic to Constantinople to defend Arianism. His cooperation with Emperor Justin (518527 ) resulted in his imprisonment in Ravenna, where he died. On the manner of John I's death we have good reason to suspect the testimony of $L P$, which claims that he died in $5^{26}$ as a result of ill-treatment at the hands of Theoder-

8 Evagrius, Historia Ecclesiastica 3.30; The Ecclesiastical History of Evagrius with the Scholia, ed. J. Bidez, L. Parmentier, London, 1898; repr. Amsterdam, 1964, p. 126.27-30; trans. M. Whitby, The Ecclesiastical History of Evagrius (Translated Texts for Historians, 33), Liverpool, 2000, p. 167. See further F.K. Haarer, Anastasius I: Politics and Empire in the Late Roman World (ARCA. Classical and Medieval Texts, Papers and Monographs, 46), Cambridge, 2006, pp. 132-136.

On Rome's relations with the eastern patriarchs from the time of the Robber Council at Ephesus (449) to the episcopacy of Agapitus, see P. Blaudeau, Le Siège de Rome et l'Orient (448-536). Étude géo-ecclésiologique (Collection de l'École française de Rome, 46o), Rome, 2013 .

$10 \quad$ Collectio Avellana 236 (26 March 521): unus de Trinitate crucifixus, in Epistulae imperatorum pontificum aliorum inde ab anno CCCLXVII usque ad annum DLIII datae, Avellana quae dicitur Collectio, ed. O. Guenther, 2 vols. (CSEL, 135), Prague - Vienna - Leipzig, 1895, p. 716. 
ic. ${ }^{11}$ Ninety-eight days after John's death, Theoderic himself died, a fact that the author of $L P$ chose to portray as punishment of the "heretic king."

\section{$4 \quad$ Felix IV $\left(5^{26-530}\right)$}

Felix IV, born in Samnium, was the third of our sixth-century popes from the provinces, and ruled in relative peace for four years, spanning the transition from Theoderic to Athalric. The $L P$ notes that he was "ordained peacefully," an indication that this was a rarity. He died in 530 of natural causes. The $L P$ author seems to be unaware that the Byzantine emperor Justin had died on 1 August 527 and was succeeded by his co-emperor, Justinian. The papal succession after Felix IV was violently disputed.

Dioscorus, Antipope (September to October 530)

Dioscorus, the candidate with majority support, was elected in the Constantinian basilica (also known as the Lateran basilica) at the same time as Boniface II was elected in the Basilica of Julius on 22 September 530, the day of Felix IV's death. Dioscorus died after 28 days of strife between the Roman clergy and the senate, on 14 October 530.

\section{Boniface II $\left(530-53^{2}\right)$}

After the death of his rival Dioscorus, Boniface ruled unchallenged for just over two years. Hoping to avoid the disorder that attended his own election, he tried to designate as his successor the deacon Vigilius, and signed a decree to this effect. However, under pressure from other bishops (sacerdotes), he was persuaded to destroy it by fire in a public demonstration. He died two years later, and the see was vacant for two-and-a-half months. Vigilius was eventu-

11 LP 1, 275-276; Anon. Vales. 88-93, in Analecta nouissima Spicilegii Solamensis, ed. J.-B. Pitra, vol. 1, Paris, 1885, p. 466. C. Sotinel, "Popes and Emperors in the Sixth Century," in: Cambridge Companion to the Age of Justinian, ed. M. Maas, (Cambridge, 2006), pp. 267290, is inclined to accept this account; see also T. Sardella, "Giovanni I," in: Enciclopedia dei Papi, vol. 1, Rome, ${ }^{2}$ 200o, pp. $483-487$. 
ally ordained bishop of Rome several years later, with the support of Emperor Justinian, who is identified as Justin in the $L P$, in 537 .

Boniface II was succeeded by John II, also known as Mercurius, son of Projectus, an aristocrat from the Caelian Hill. John II endorsed a statement of faith sent to him by Emperor Justinian (527-565), thus reversing previous papal condemnations of the Theopaschite formula, the phrase that was added to the Trisagion hymn in the time of Hormisdas. ${ }^{12}$ He died within three years, in 535 , and was succeeded by Agapitus after six days.

8

Agapitus (535-536)

Pope Agapitus, son of a priest, had held the see of Rome for just under a year when he was sent to Constantinople on an embassy for the Gothic king Theodahad, who needed to make peace with the emperor after imprisoning his cousin, Theoderic's daughter Amalasuintha, who ruled the Ostrogoths as regent from 526 to 534 . She was killed in exile in 534 or 535 . Pope Agapitus annoyed Justinian with his condemnation of the anti-Chalcedonian patriarch of Constantinople, Anthimus, who would not confess two natures in Christ. Justinian was forced to excommunicate and exile his patriarch, replacing him with the Chalcedonian Menas. Agapitus did not live long enough to enjoy his triumph over the emperor and the heretical Patriarch Anthimus. He was mysteriously struck ill and died "several days later" in Constantinople, on 22 April 536 (the same day as he arrived, according to $L P$ - there is an internal inconsistency here). ${ }^{13}$ His body was returned to Rome in a lead coffin for burial, and his successor was ordained by Theodahad after two months. ${ }^{14}$

9

Silverius $\left(53^{6-537)}\right.$

Silverius, the son of Hormisdas, and born in the province of Campania like his father, was ordained by the Ostrogothic king (or "tyrant" as $L P$ has it)

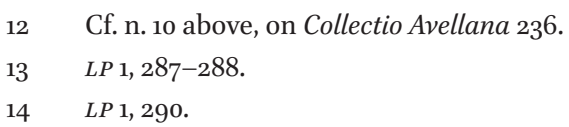


Theodahad, who allegedly accepted a bribe to install Silverius "without consultation." 15 The clergy of Rome who refused to ratify his ordination were put to the sword. Two months later, Theodahad was "snuffed out by God's will."16 Vitiges succeeded him as leader of the Goths and attacked Naples, then Rome, sparking thirty years of conflict known as the Gothic wars. Justinian sent the general Belisarius with an army "to free all of Italy from the occupation of the Goths". ${ }^{17}$ Like his predecessor, Silverius refused to approve the restoration of Anthimus to the patriarchate of Constantinople, thus angering Justinian.

Silverius seems to have trusted the wrong man in his appointment of the archdeacon Vigilius as papal emissary (apocrisiarius) to Constantinople. Vigilius promised Justinian that he would restore Anthimus to the patriarchate, and in return he was promised the Roman pontificate. He was sent back to Rome to depose Silverius with a false accusation that he had betrayed Rome to the Goths. Silverius had ruled for just nine months, from June 536 to March 537 . Vigilius sent him into exile at Pontiae, where the Liber Pontificalis relates that, having been fed on "the bread of distress and the water of affliction," Silverius "grew weak, died and became a confessor,"18 a posthumous recognition of his stand against Patriarch Anthimus and the anti-Chalcedonians. He abdicated eight months later, and died the following month, on 2 December 537. From this point onwards, only candidates with Byzantine support were ordained, and pontificates lengthened accordingly.

Meanwhile, Vigilius had been installed as pope for eight months, since 29 March 537. The accession of Vigilius, born in Rome and son of a consul of the city, marks a low point in the papacy and its relations with its own citizenry as well as with the Byzantine emperor and the church of Constantinople. While his pontificate was relatively long, only seventeen of his letters survive. Deacon and apocrisiarius to Constantinople, his reign was marred from the start by his complicity in the deposition and death of his predecessor. His pontificate was dominated by the Three Chapters controversy. From the outset, the clergy of Sardinia, Africa, Milan and Rome remained united in their acceptance of the

$\begin{array}{ll}15 & L P 1,290 . \\ 16 & L P 1,290 . \\ 17 & L P 1,290 . \\ 18 & L P 1,293 .\end{array}$


Three Chapters, which had been endorsed at the Council of Chalcedon, and their authors. ${ }^{19}$

At the end of 545, on the eve of the Gothic invasion, Vigilius left Rome with almost his entire clergy under Byzantine military escort, stopping for more than a year in Sicily en route to Constantinople. From 547 until 554 he was subjected to imperial pressure to accede to the condemnation of the Three Chapters. His attempts to find a compromise met with serious opposition in the West, particularly in Africa where the pope was excommunicated. Vigilius was forced to swear his allegiance to Justinian in condemning the Three Chapters, the allegedly anti-Chalcedonian writings of Theodoret of Cyrrhus, Theodore of Mopsuestia and Ibas of Edessa. After four years of indecision he fled to the Church of St Euphemia in Chalcedon, but was persuaded to return to the capital in 552. He continued to vacillate until December 553, condemning the Three Chapters in a second letter to Eutychius, bishop of Constantinople, known as the Scandala. ${ }^{20}$ The emperor was not satisfied, however, and Vigilius had to repeat the condemnation of Theodoret of Cyrrhus, Theodore of Mopsuestia and Ibas of Edessa and their works in the Constitutum II, dated 23 February $554 .{ }^{21}$ Having thrown his lot in with the Byzantine court, Vigilius lasted eighteen-and-a-half years as pope, but on his way back to Rome after three years of effective house arrest in Constantinople, he died (again mysteriously) at Syracuse, "in agony from his affliction with gallstones," on 7 June $555{ }^{22}$

11

\section{Pelagius I $\left(55^{6}-561\right)$}

The archdeacon of Agapitus and Vigilius, Pelagius I's rule was consumed by the Three Chapters controversy and the reconstruction of Rome after two decades of destruction throughout the Gothic wars, facilitated by the Pragmatic Sanction of Emperor Justinian. ${ }^{23}$ Pelagius was the candidate of the Byzantine

19 A case-study of Vigilius' involvement in the Three Chapters dispute is found in P. Allen, B. Neil, Crisis Management in Late Antiquity (410-59o CE): A Survey of the Evidence from Episcopal Letters (Suppl vc, 121), Leiden, 2013, pp. 58-61.

20 Vigilius, Scandala, in Concilium universale Constantinopolitanum sub Iustiniano habitum ( $A D$ 553), ed. E. Schwartz, J. Straub (Acta Conciliorum Oecumenicorum, 4.1), Berlin Leipzig, 1971, pp. 245-247.

21 Vigilius, Aetius, ed. E. Schwartz (Acta Conciliorum Oecumenicorum, 4.2), Berlin - Leipzig, 1914, pp. 138-168.

$22 \quad L P 1,299$.

23 This imperial edict on the reorganization of Italy after the Gothic wars was issued in August 554. 
general Narses, and was seen by the Roman and northern Italian clergy as a traitor to the cause of Theodoret of Cyrrhus, Ibas of Edessa and Theodore of Mopsuestia. As a consequence, he was not accepted by the Roman clergy or the nobility, and had trouble finding a bishop to ordain him. He also had trouble with the Gallic bishops, prompting him to send a confession of faith to their king, Childebert, ${ }^{24}$ asking him to stop those who were causing divisions in the Gallic church. In an open letter to "all the people of God," he sought to remove all suspicion about the orthodoxy of the see of Rome by sending his profession of faith, even accepting Theodoret of Cyrrhus and Ibas of Edessa as orthodox. ${ }^{25}$ He claimed that even while he was apocrisiarius for Vigilius in Constantinople, he wrote a refutation of Vigilius (which does not survive), as well as six books in defence of the Three Chapters. ${ }^{26} \mathrm{He}$ did however send for supplies of clothing from Sapaudus, bishop of Arles, and appealed to Boethius, praetorian prefect in Africa, to help with the refugee problem in Italy. ${ }^{27} \mathrm{He}$ also offered produce from the papal estates to combat starvation in Rome. ${ }^{28}$ Pelagius I died of natural causes in 561 after six years as bishop, although the $L P$ counts it as 11 years 10 months, ${ }^{29}$ an indication that record-keeping in the papal scrinium was breaking down.

John III $\left(5^{61-574)}\right.$

The Rome-born John III lasted almost 13 years as pope, with the support of the Byzantine general Narses, who defended Italy against the attacks of the Heruli and the Franks. The Roman people then sent a petition against Narses to Justin

24 Pelagius I, Ep. 7 to Childebert, in Pelagii I Papae epistulae quae supersunt (556-561), ed. P.M. Gassó, C.M. Batlle (Scripta et Documenta, 8), Montserrat, 1956, p. 25.

25 Pelagius I, Ep. 11 to all the people of God, in Pelagii I Papae epistulae, ed. Gassó, Batlle, pp. 35-40.

26 Pelagius I, Ep. 8 o to Symeon illustris, in Pelagii I Papae epistulae, ed. Gassó, Batlle, pp. 196197. See C. Sotinel, "Pelagio I," in: Enciclopedia dei Papi, vol. 1, Rome, ${ }^{22000,}$ pp. 529-536; and N. Ertl, "Diktatoren frühmittelalterlicher Papstbriefe," Archiv für Urkundenforschung, NF 1, 1 (1937), S. 56-132, esp. 68-70. On the themes of Pelagius' corpus of circa 100 letters, see B. Neil, "De Profundis: The Letters and Archives of Pelagius I (556-561)," in: Collecting Early Christian Letters: From the Apostle Paul to Late Antiquity, ed. B. Neil, P. Allen, Cambridge, 2015, pp. 206-220, esp. 211-212.

27 Pelagius I, Ep. 4 to Sapaudus, in Pelagii I Papae epistulae, ed. Gassó, Batlle, pp. 11-13; Ep. 85 to Boethius, ibid., 207-208.

28 Pelagius I, Ep. 4.9, in Pelagii I Papae epistulae, ed. Gassó, Batlle, p. 13.

$29 \quad L P 1,303$. 
II (wrongly identified as Justinian in $L P$ ), ${ }^{30}$ accusing the general of cruelty. Narses moved to Naples and allegedly invited the Lombards to invade Italy, then was invited back to Rome by John III to defend the city from Lombard attack. John III sought safety outside the city, moving his household to the cemetery of Tiburtius and Valerian on the Appian Way, and "even consecrated bishops there," until Narses agreed to return to Rome. ${ }^{31}$ After John's death the bishopric was vacant for 10 months.

\section{Benedict II $\left(575^{-579)}\right.$}

Benedict, elected in 575, was the fourth consecutive son of Rome to hold the pontificate. His reign was afflicted by the Lombard invasions and siege of many Italian cities, including Rome. Four years later, the population of Rome and much of Italy was reduced to starvation by siege. Benedict II died in 579, "in the midst of these labours and afflictions," as the $L P$ author puts it, ${ }^{32}$ leaving the see vacant for three months.

\section{Pelagius II $(579-590)$}

Benedict's successor Pelagius II was born into the Rome-based family of the Goth Unigild. He was ordained without an imperial mandate because of the devastation being caused by Lombards, who captured the cities of Sutrium, Polymartium, Horta, Tuder, Ameria, Perusia, and Lucioli, among others. ${ }^{33}$ The Lombard presence had apparently blocked the channels of communication with Constantinople. He sent his apocrisiarius Gregory (the future pope Gregory I) to petition Emperor Maurice for help, to no avail. ${ }^{34} \mathrm{~A}$ sign of the desperate times is the notice in $L P$ that Pelagius II turned his episcopal palace into an

$30 \quad L P 1,305$.

$31 \quad L P 1,305$. See M. Humphries, "From emperor to pope? Ceremonial, space, and authority at Rome from Constantine to Gregory the Great," in: Religion, Dynasty, and Patronage in Early Christian Rome, 300-9oo, ed. K. Cooper, J. Hillner, Cambridge, 2007, pp. 21-58, esp. 56 .

$32 \quad L P 1,308$.

$33 L P 1,312$.

34 Pelagius II, Ep. 1 to Maurice, in Registrum Gregorii Magni, ed. L. Hartmann (Monumenta Germaniae Historica Episulae, 2), Berlin, 1899, pp. 440-441. 
almshouse for theaged poor. ${ }^{35}$ Pelagius died eleven years afterhis consecration, ${ }^{36}$ perhaps as a result of the plague which followed the flooding of the Tiber River in 589 .

The bishopric was vacant for almost seven months, before the election of Gregory I, whose election took seven months to be ratified by the Byzantine emperor Maurice. In c. 595, Gregory successfully appealed to the exarch of Ravenna, Romanus, who freed Rome and many of the other sees captured by Lombards during the pontificate of Pelagius II, resulting in a tenuous peace being concluded with the Lombards. ${ }^{37}$ Gregory's struggle to resolve the tension between his desire for a life of contemplation in monastic seclusion, and the demands of pastoring a church whose threatened patrimonies stretched from Sicily to the Balkans, is a major theme of early hagiographers of his life, as well as his own works. Gregory himself seems to have died peacefully enough but was barely remembered in his own time. John the Deacon's preface to the lateninth century Life of Gregory notes the request of Pope John VIII (872-882) for a Life of Gregory, since the English and Lombards had one, but not the Roman church, surely a witness to the disruption of the times, although his successor may have had some influence in the lack of commemoration of this monastic pope (see 'Sabinian' below). ${ }^{38}$ John's Life records Gregory's aid to the nameless poor, through distributions of food - grain, wine, cheese, vegetables, meat, fish and oil - and sending out from the Lateran palace a "meals on wheels" service for the sick. According to John the Deacon, the pope also shared his own table with refugees, almost certainly homeless aristocrats who had been displaced by the Lombard invasions. ${ }^{39}$

$35 \quad L P 1,309$.

$36 \quad L P 1,309$.

$37 L P 1,312$. On Gregory's complex attitude towards Byzantine sovereignty over Rome, see the discussion of M. Dal Santo, "Gregory the Great, the Empire and the Emperor," in: A Brill Companion to Gregory the Great, ed. B. Neil, M. Dal Santo (Brill's Companions to the Christian Tradition, 47), Leiden, 2013, pp. 57-81.

38 John the Deacon, Vita Gregorii Magni, in PL 75, col. 61.

39 John the Deacon, Vita Gregorii Magni, 2.24-30, in PL 75, col. 96D-98A. 
Gregory's successor Sabinian was part of the opposing clerical faction, and perhaps had a hand in suppressing the memory of his predecessor. Like Gregory, he had been papal apocrisiarius to Constantinople and deacon of the Roman church before his appointment to the pontificate. Sabinian himself sank to new levels of unpopularity during his eighteen-month rule, after he attempted to sell papal grain stores to the starving people of Rome at exorbitant rates. Although $L P$ does not say how he died, it does mention his sale of grain for the price of one gold coin (solidus) for 30 modii. ${ }^{40}$ Sabinian's funeral procession around the city was disrupted by riots, but $L P$ does not say more than that the procession was taken out of the city by St John's gate and conducted outside city walls to the Milvian Bridge. ${ }^{41}$ The Whitby monk who composed the first Life of Gregory the Great in c. 713 gave a surprisingly violent account of a dream in which Sabinian's predecessor appeared to him. When Gregory I reproached him for his jealousy and greed at the expense of the Roman people, Sabinian remained obdurate and unrepentant, so Gregory kicked him in the head, causing his death. ${ }^{42}$ One might wonder how Sabinian found time to report his nightmare before his untimely demise.

\section{7 \\ Conclusion}

To sum up our brief survey of the Roman pontificates of the sixth and early seventh centuries: after the relative stability of the pontificate of Hormisdas, the next six bishops of Rome up to Silverius (excluding the anti-pope Dioscurus) lasted only fourteen years altogether, from 523 to 537 , and their brief rules generally ended in prison, in exile, or in sudden death in mysterious circumstances. Conflict between the Gothic kings and Byzantine emperors accounted for the deaths of three - John I, Agapitus, and Silverius - who were caught in the crossfire, so to speak. Four of the earlier popes came from the provinces, but from the installation of the first Byzantine candidate, Vigilius, in 537, all

$40 \quad L P 1,315$. One modius equalled $6.67 \mathrm{~kg}$ of wheat in the Roman measuring system, according to G. Rickman, The Corn Supply of Ancient Rome, Oxford, 1980, p. xiii.

$41 \quad L P 1,315$.

42 Anonymous of Whitby, Liber beati et laudabili viri Gregorii papae urbis Romae de vita atque eius virtutibus, in B. Colgrave, ed., trans., "The Earliest Life of St Gregory the Great, Written by a Whitby Monk," in: Celt and Saxon: Studies in the Early British Border, ed. N. Chadwick, Cambridge, 1963, pp. 119-137, at 126. 
successful candidates were born in Rome. Even Vigilius eventually fell out of favour with the Byzantine court, and died on his way home from several years of house arrest in Constantinople. After 555, increased Byzantine control over the papacy meant that imperial candidates generally lasted a lot longer, from four to thirteen years, even though the turbulent circumstances induced by the Gothic wars and the Lombard invasions brought famine, plague, and death to many citizens of Italy. Pelagius I, Pelagius II and Gregory I apparently tried to help the poor and starving by interceding on their behalf and making supplies of food, clothing and money available to them. Gregory died in his bed, as did his successor, but Sabinian's funeral was disrupted by protests from the poor who had suffered from his exploitation of the papal grain supply for his own profit. All in all, it is not a pretty picture for the century under examination, and certainly lends irrefutable evidence to an assessment of the balance as falling towards decline rather than progress in Rome during this period, just before the beginning of the Dark Ages. 